DOI: $10.30519 /$ ahtr.933696

Advances in Hospitality and Tourism Research (AHTR)

\title{
HOW HOTEL BRAND WEBSITE CONTRIBUTES TO ONLINE HOTEL RESERVATION ON CONSUMER REVIEW WEBSITE?
}

\author{
Nuttapol ASSARUT ${ }^{1}$ \\ Marketing Department, Chulalongkorn Business School, Thailand \\ ORCID: 0000-0003-4403-4889 \\ Somkiat EIAMKANCHANALAI ${ }^{2}$ \\ Marketing Department, Chulalongkorn Business School, Thailand \\ ORCID: 0000-0001-6370-998X
}

\begin{abstract}
While past research only attempted to investigate the impact of consumer review website characteristics on the hotel reservation behavior, this study incorporated both characteristics of hotel brand website and consumer review website into consideration. Impacts of the two types of websites on reservation behaviors in consumer review websites were examined. The moderating effects of consumer involvement and risk aversion factors were also considered. Three hundred and two respondents from the questionnaire survey were chosen from Bangkok metropolitan population aged 25-60, who experienced with online hotel reservations. The findings show that apart from the review website's ease of use, information usefulness and price offered, brand website's information usefulness also has positive impact on consumers' decisions on the review website. However, brand website's ease of use discourages the usage of the review website. High-risk aversion consumers tend to use the review websites, while high-involvement consumers pay less intention to the review websites' information usefulness and are unlikely to use them. These findings will help managers effectively manage and design decision algorithm for their multi-channels of hotel ecommerce. The results explain dynamic, search sequence and interrelationship of current traveler's behaviors. The source of their hotel search is both consumer review website and hotel brand website.
\end{abstract}

\section{Article History \\ Received 6 May 2021 \\ Revised 26 August 2021 \\ Accepted 15 November 2021 \\ Published online 7 Mar. 2022}

\section{Keywords}

consumer review website hotel brand website consumer involvement risk aversion online hotel reservation website characteristic

1 Address correspondence to Nuttapol Assarut (Ph.D.), Marketing Department, Chulalongkorn Business School, Bangkok, Thailand. E-mail: nuttapol@cbs.chula.ac.th

${ }^{2}$ Address correspondence to Somkiat Eiamkanchanalai (Ph.D.), Marketing Department, Chulalongkorn Business School, Bangkok, Thailand. E-mail: somkiat@cbs.chula.ac.th 


\section{INTRODUCTION}

Today's consumers alter their ways in decision making toward purchases, especially their information search behaviors (Gursoy, 2019). This, in turn, has affected how marketers communicate to their customers. In the travel industry, consumers regard the Internet information search as a significant process in vacation preparation (Sun et al., 2017; Xiang \& Gretzel, 2010).

Generally, companies use hotel brand website to market their products and services. However, consumers rely on the more popular consumer review websites, i.e., Agoda, Booking.com, Expedia.com, etc., due to the consumer review websites' review feature. This evolution encouraged researchers to investigate the way people look for information online as well as its effect on consumer decisions.

In an early study, Flanagin and Metzger (2000) found that the information from the Internet as reliable as other traditional media, but not as trustworthy as a newspaper. In the hotel industry, the emergence of ecommerce led some hotels to develop hotel reservation features on their official websites, which drew researchers to investigate the factors that motivated consumers to make reservations through hotel brand website (Bai et al., 2008; Kim \& Kim, 2004; Li et al., 2017; Ongsakul et al., 2021; Wang et al., 2015; Yeung \& Law, 2004). However, information founded on the Internet was a one-way communication and relatively static in these studies.

Later, the Internet platforms evolved into virtual community websites, i.e., web boards, forums, etc., where information exchange among customers is allowed. Some websites have evolved further by combining more e-commerce functions. As a result, the Internet community website has transformed the way consumers shop online by integrating user's review with marketplace functions. This has set a new standard and shifted more studies on the topic of online communities (Sigala, 2011a, 2011b). Some studies explored the influence of consumer review website feature on consumer purchase intention and trust (Casaló et al., 2010, 2011; Ong, 2012; Park et al., 2007; Sparks \& Browning, 2011).

During the hotel reservation process, despite the popularity of consumer review websites, consumers tend to search both consumer review website and hotel brand website for hotel information, and it is possible that customers make reservations on both websites (McCarthy et al., 2010; Sun et al., 2016). Thus, hotel brand website and review website are alternate 
channels that compete with and affect each other when customers search for hotels.

However, past research has studied consumer decisions in the context of either hotel brand website or consumer review website. Some studies attempted to compare customer decisions on the two types of websites (Morosan \& Jeong, 2008; Liu \& Zhang, 2014). However, these studies did not investigate how the two websites affected each other or the interaction effect of the websites in the consumer decision process. In other words, there is little investigation into how hotel brand website contributes to the consumer decision process in consumer review website (Masiero \& Law, 2016; Morosan \& Jeong, 2008; Liu \& Zhang, 2014).

To fill this gap, this study aims to compare the impact of characteristics of hotel brand website and those of consumer review website on consumer decision-making process for consumer review websites. In addition, perceived risk in purchase decision was lowered as a result of online review information (Goldsmith \& Horowitz, 2006; Nadiminti et al., 1996). However, it remains untested whether the risk factor has an effect in the context of online hotel reservation when hotel brand website is considered together with consumer review website. Moreover, the degree of consumer involvement is also introduced here because it should have an impact on buyer purchase decision within the information search stage, as it may moderate the effect of hotel brand website and consumer review website. As a result, the consumer risk aversion factor and the degree of consumer involvement factor are incorporated into the research framework as moderators.

It is inevitable that hotel booking through consumer review website plays an important role in the hotel business (Liu \& Zhang, 2014; MartinFuentes \& Mellinas, 2018). However, communication through hotel brand website is indispensable in building a hotel brand (Wang et al., 2015). The results of this study can provide key evidence that guides managers in designing a hotel reservation system on their websites, as well as consumer review websites. This will create a mechanism by which hotel brand website can help support the decision-making process of consumers when making hotel reservation through consumer review website.

\section{LITERATURE REVIEW}

The key factors that impact online hotel booking decisions can be classified into three categories: customer-based antecedents, which refer to the past 
experiences of the customer; company-based antecedents, which consist of the reputation of the website owner; and website-based antecedents, which comprise usefulness, ease of use, and website quality (Agag \& El-Masr, 2017; Beldad et al., 2010; Filieri et al., 2015). This study aims to examine the antecedents of customer decisions when using consumer review websites compared to hotel brand website, and the analysis level is the website platform. Thus, the antecedents highlighted in this study are the websitebased antecedents, which consist of four factors: information usefulness, ease of use and convenience, price and promotion, and review information.

\section{Information Usefulness}

The perceived usefulness and perceived ease of use factors are considered the key determining factors in the technology adoption model (TAM), which explains the mechanism behind customers' adoption of new technology (Davis, 1989; Venkatesh \& Davis, 2000). In the online hotel reservation environment, perceived usefulness referred as how the tourists think whether online hotel booking is useful, which, in turn, can improve performance, productivity, or effectiveness of the booking process (Agag \& El-Masry, 2016; Bhatiasevi \& Yoopetch, 2015; Ozturk et al., 2016). Usefulness is a significant factor people consider when making online reservations (Ranganathan \& Grandon, 2002; Wong \& Law, 2005). It has a positive effect on trust (Li et al., 2017), attitude (Agag \& El-Masry, 2016), behavior intention (Agag \& El-Masry, 2016; Bhatiasevi \& Yoopetch, 2015; Kim \& Kim, 2004) and customer loyalty (Ozturk et al., 2016).

Past research found that the availability and efficiency of the information on hotel websites represents the functionality and usability of websites (Yeung \& Law, 2004). Based on these results, Bai et al. (2008) found that the two aspects of information usefulness had positive effects on consumer responses in terms of website satisfaction and hotel booking intention, while Wang et al. (2015) found that they had a positive influence on consumer response in terms of online hotel trust and booking intention. The results were also confirmed by Li et al. (2017), who found positive effects of website information usability on e-trust and online booking intention. Hence, it follows that:

H1: The information usefulness of consumer review websites positively affects consumer response to consumer review websites.

H2: The information usefulness of hotel brand website negatively affects consumer response to consumer review websites. 


\section{Ease of Use}

Ease of use is another element of website that encourages the customer to conduct information search and make decisions on the website. It refers to how the website is easy to use, easy to understand, and convenient to access (Aziz \& Kamaludin, 2014). It is also one of the fundamental factors in TAM, together with the perceived usefulness, and has been adopted to investigate online hotel reservation behavior (Agag \& El-Masry, 2016; Lockyer, 2005; Ozturk et al., 2016).

Agag and El-Masry (2016) reported that ease of use positively affected attitude and behavior of consumers on online travel websites. Bhatiasevi and Yoopetch (2015) found a positive effects of ease of use on intention to book hotels or air tickets on online platforms. More specifically, some studies found that the convenience of use of hotel websites had a positive impact on hotel reservation (Kim \& Kim, 2004; Kim et al., 2006), while Ozturk et al. (2016) showed that ease of use positively affected customer loyalty. In addition, Morosan and Jeong (2008) found that ease of use had a positive impact on attitudes and intention to use both consumer review websites and hotel brand website. Hence:

H3: Ease of use of consumer review websites positively affects consumer response to consumer review websites.

H4: Ease of use of hotel brand website negatively affects consumer response to consumer review websites.

\section{Price Offered}

Price is one of the major factors in hotel reservations (Law \& Hsu, 2006). Research confirmed that price discounts have a positive effect on purchase intentions (Faryabi et al., 2012; Kim et al., 2006). Consumers search for the best price from the Internet (Kim \& Gupta, 2009; Wong \& Law, 2005). Moreover, it was also found that price affected how consumers evaluate hotel value and thus impacted consumers' intention to purchase (Chiang \& Jang, 2007; Lockyer, 2005).

In a study of hotel brand website, it was found that a reasonable price had a positive impact on hotel reservation (Chiang \& Jang, 2007; Kim \& Kim, 2004; Kim et al., 2017; Lien et al., 2015). A study of consumer review websites also found that price played an importance role in decisionmaking (Liu \& Zhang, 2014). Perceived price led to bias in hotel reviews that indirectly affected booking intention (Li \& Hitt, 2010). Therefore, the hypothesis is as follows: 
H5: The price offered on the consumer review website positively affects consumer response to the consumer review website.

When consumers browse for the most reasonable price, they compare prices between sources, including hotel brand website and consumer review websites. This means that the two websites are competing, and the price information shown on one website will have a negative impact on the other. Thus, we propose the hypothesis as follows:

H6: The price offered on hotel brand website negatively affects consumer response to consumer review websites.

\section{Peer Experience}

Customer review information or peer experience is a unique characteristic of consumer review websites that is distinctive from the information provided on hotel brand website. Several works have attempted to investigate the impact of customer reviews on hotel performance (Xie et al., 2014), trust (Sparks \& Browning, 2011; Sparks et al., 2016), and hotel booking intention (Casaló et al., 2015a; Mauri \& Minazzi, 2013; Sparks \& Browning, 2011; Tsao et al., 2015). Zhao et al. (2015) empirically showed that online reviews had a direct impact on hotel booking intentions. Kim et al. (2017) reported that online reviews had an impact on hotel trust and online booking intentions.

In the case of a consumer review website, the hotel review is the key feature and provides information about the past experiences of other customers with the hotel. It is expected that the availability of peer experience will help people compare and evaluate hotels, leading to trust, satisfaction and intention to book hotels on the review website. Thus, the following hypothesis is proposed:

H7: Peer experience on consumer review websites positively affects consumer response to consumer review websites.

\section{Risk Aversion}

Past research found that website security, including privacy and safety, was one of the dominant factors predicting consumer hotel online booking behavior (Kim \& Kim, 2004; Wang \& Wang, 2010, Wong \& Law, 2005). A study focusing on the characteristics of websites investigated the impact of perceived website risk on hotel booking intentions (Agag \& El-Masry, 2016, Kim \& Kim, 2004; Wang et al., 2015). 
Another research stream focuses on the risk aversion characteristics of customers, which is the highlighted factor in this study. Studies suggest that consumers search for more information to lower risk (Goldsmith \& Horowitz, 2006; Nadiminti et al., 1996). High risk averse people are most likely to exhaustively seek for information, but the low-risk averse people tend to search from one source of information (Jordan et al., 2013; Money \& Crotts, 2003; Quintal et al., 2010). Casaló et al. (2015b) found that high risk averse travelers tend to rely on positive review information than low risk averse travelers.

Risk aversion measurement of past research was employed by several techniques. Most of the research developed ad hoc measurements to scale one's degree of risk aversion (Floyd et al., 2004; Slevitch \& Sharma, 2008). Kapferer and Laurent (1993) developed a general scale to measure consumer involvement, which includes the risk importance factor and probability of the error factor as the key dimensions in the measurement. The findings from past research suggest that risk aversion tends to be domain specific. Consumers with different backgrounds have varying tolerance of risk taking in varying domains (Slevitch \& Sharma, 2008).

The risk aversion construct is combined into the analysis model to investigate how customer risk aversion moderates the effect of consumer review website and hotel brand website on consumer response to consumer review website. Accordingly, the following hypothesis has been posited:

H8a: Customer risk aversion moderates the effect of the convenience of consumer review websites on consumer response to Consumer review websites.

H8b: Customer risk aversion moderates the effect of the convenience of hotel brand website on consumer response to consumer review websites.

H8c: Customer risk aversion moderates the effect of the information usefulness of consumer review websites on consumer response to consumer review websites.

H8d: Customer risk aversion moderates the effect of the information usefulness of hotel brand website on consumer response to consumer review websites.

H8e: Customer risk aversion moderates the effect of price in the consumer review website on consumer response to the consumer review website.

H8f: Customer risk aversion moderates the effect of price in hotel brand website on consumer response to consumer review websites.

H8g: Customer risk aversion moderates the effect of review information on consumer response to the consumer review website. 


\section{Consumer Involvement}

Involvement is a popular concept in the consumer research. The concept suggests that the information search behavior of consumers in the decisionmaking process relies heavily on the magnitude of consumer involvement (Kim et al., 2011; Lehto et al., 2006). Past research suggests that involvement is a situation-specific concept. This means that people's degree of involvement with a product or service is different depending on the decision-making context. For example, travelers' degree of involvement in hotel selection when traveling to a familiar destination may differ from that when traveling to an unfamiliar destination (Laurent \& Kapferer, 1985).

Kapferer and Laurent (1993) proposed a multidimensional scale to measure consumer involvement. Their studies introduced five antecedents of consumer involvement: pleasure, interest, sign, probability of error, and risk importance (Kapferer \& Laurent, 1993; Laurent \& Kapferer, 1985). The risk importance and probability of error antecedents determine the consumer's degree of risk aversion. As risk aversion is treated as a separate moderator in this study. Thus, consumer involvement factor in this study is measured by the three antecedents: interest, pleasure, and sign, proposed by Kapferer and Laurent (1993).

Past studies found that consumers with high involvement focus on the product information in their decision makings (Petty et al., 1983) and concern more on quality of information (Park et al., 2007). On the other hand, low involvement consumers tend to concern more on quantity of information in decision makings (Park et al., 2007), which are ratings and customer reviews (Park \& Lee, 2008). In the context of hotel booking, Bandi et al. (2018) found that low involvement consumers tend to make decision on consumer review website, while those with high involvement preferred to search for information from other sources.

Similar to risk aversion factor, the moderating effects of customer involvement on the effects of consumer review website and hotel brand website on consumer response to consumer review website were also tested in this study. Therefore, the associated hypotheses are as follows:

H9a: Customer involvement moderates the effect of the convenience of consumer review websites on consumer response to consumer review websites.

H9b: Customer involvement moderates the effect of the convenience of hotel brand website on consumer response to consumer review websites.

H9c: Customer involvement moderates the effect of the information usefulness of consumer review websites on consumer response to consumer review websites. 
H9d: Customer involvement moderates the effect of the information usefulness of hotel brand website on consumer response to consumer review websites.

H9e: Customer involvement moderates the effect of price in consumer review websites on consumer response to consumer review websites.

H9f: Customer involvement moderates the effect of price in hotel brand website on consumer response to consumer review websites.

H9g: Customer involvement moderates the effect of review information on consumer response to consumer review website.

\section{METHODOLOGY}

Three hundred and two respondents were selected from Bangkok metropolitan population aged 25-60 using questionnaire survey. Judgmental sampling was utilized with the criteria that the respondents must have experience traveling abroad and decided their own online hotel reservations.

In data collection process, the respondents described their hotel reservation behaviors in a situation where they were to vacation in an unfamiliar destination. The first section of the questionnaire is a set of questions to collect the respondents' socioeconomic profiles. Next, based on five-point Likert scale, the respondents rate their risk aversion in hotel decisions, their involvement with hotels, their motivation to use consumer review websites, and hotel brand website according to the websites' characteristics. Finally, satisfaction, intention, and probability of changing their hotel selection on the consumer review website were collected.

Risk aversion measurement is derived from risk importance factors and the probability of error factors in Kapferer and Laurent's (1993) consumer involvement scale. Additional questions were developed based on the risk concept proposed by Slevitch and Sharma (2008) to cover functional risk, social risk, and financial risk. As a result, there are fourteen questions for risk aversion. The eight questions about consumer involvement were derived from interest factors, pleasure factors, and significant factors in Kapferer and Laurent's (1993) involvement scale. One question in the consumer involvement scale was dropped according to a suggestion from the pretest (Appendix A).

The original 16 questions to evaluate website characteristics are adopted from Kim et al. (2011). After conducting a pretest with ten respondents, several questions were modified and dropped from the measurement because they did not fit with the context of consumer review 
websites and hotel brand website in Thailand. Ultimately, there were thirteen questions for hotel brand website and sixteen questions for consumer review websites (Appendix A).

\section{RESULTS}

\section{Sample Profile}

The sample profile and travel behavior are shown in Table 1. The sample was evenly distributed across gender and age groups between 25 and 44 years, with a slight dip in the 45 years and above group. The number of respondents with a bachelor's degree and lower was approximately the same as the number with higher than bachelor's degree. The majority of respondents (57.61) have monthly incomes between 1,001-1,500 Euro. On average, $63.91 \%$ of the respondents traveled abroad once a year.

Table 1. Summary of sample characteristics

\begin{tabular}{|c|c|c|c|}
\hline Variables & Categories & $\begin{array}{l}\text { Frequency } \\
\qquad(\mathrm{n}=302)\end{array}$ & $\begin{array}{c}\text { Percentage } \\
(\%)\end{array}$ \\
\hline \multirow[t]{2}{*}{ Gender } & Male & 147 & 48.68 \\
\hline & Female & 155 & 51.32 \\
\hline \multirow[t]{5}{*}{ Age } & $25-29$ & 85 & 28.15 \\
\hline & $30-34$ & 60 & 19.87 \\
\hline & $35-39$ & 68 & 22.52 \\
\hline & $40-44$ & 55 & 18.21 \\
\hline & 45 and above & 34 & 11.26 \\
\hline \multirow[t]{2}{*}{ Education } & Bachelor's degree and lower & 127 & 42.05 \\
\hline & Higher than bachelor's degree & 175 & 57.95 \\
\hline \multirow[t]{6}{*}{ Monthly income } & 500 Euro and lower & 30 & 9.93 \\
\hline & 501-1,000 Euro & 90 & 29.80 \\
\hline & 1,001-1,500 Euro & 84 & 27.81 \\
\hline & 1,501-2,000 Euro & 43 & 14.24 \\
\hline & Higher than 2,000 Euro & 52 & 17.22 \\
\hline & N.A. & 3 & 0.99 \\
\hline \multirow[t]{3}{*}{ Status } & Single & 164 & 54.30 \\
\hline & Married & 129 & 42.72 \\
\hline & Other & 9 & 2.98 \\
\hline \multirow{4}{*}{$\begin{array}{l}\text { Frequency of travel } \\
\text { abroad each year }\end{array}$} & Less than once a year & 39 & 12.91 \\
\hline & Once a year & 193 & 63.91 \\
\hline & Twice a year & 56 & 18.54 \\
\hline & More than twice a year & 14 & 4.64 \\
\hline \multirow{4}{*}{$\begin{array}{l}\text { How do you search for } \\
\text { hotel information online? }\end{array}$} & Consumer review website & 30 & 9.93 \\
\hline & Hotel brand website & 98 & 32.45 \\
\hline & Consumer review website then Hotel brand website & 28 & 9.27 \\
\hline & Hotel brand website then Consumer review website & 146 & 48.34 \\
\hline
\end{tabular}

As for respondents' online hotel search behavior, the majority (48.34\%) started searching from hotel brand website then moved to consumer review websites. Some only searched in one type of websites. Respondents who searched only in hotel brand website were 32.45 percent and only in consumer review websites were 9.93 percent. Only small 
proportion of the respondents commenced search from consumer review websites then made further search in hotel brand website (9.27\%). These indicated that the hotel brand website plays a more important role than consumer review websites.

\section{Characteristics of Consumer Review Websites and Hotel brand website}

The questions related to consumer review website and hotel brand website characteristics were subjected to principal component analysis with varimax rotation to identify the construct of the measurements. The results revealed seven factor constructs, including four factors for consumer review website characteristics and three factors for hotel brand website characteristics (Table 2). The Kaiser-Meyer-Olkin (KMO) index is equal to 0.814 with $75.98 \%$. of cumulative variance explained. The communality values of all questions are greater than 0.600. Some items were dropped from the analysis in this step due to the low factor loadings. The factor loadings of the remaining items were greater than 0.400. Overall, the indicators showed acceptable measurement reliability.

Table 2. Components of customer review website and hotel brand website characteristics from the principal component analysis

\begin{tabular}{|c|c|c|c|c|c|}
\hline Variables & Items & $\begin{array}{c}\text { Factor } \\
\text { loadings }\end{array}$ & Communality & $\begin{array}{c}\text { Rotation Sums } \\
\text { of Squared Loadings }\end{array}$ & $\begin{array}{c}\% \text { of } \\
\text { Variance }\end{array}$ \\
\hline \multirow[t]{3}{*}{ RW Information usefulness } & RW14 & 0.687 & 0.688 & 1.892 & 8.225 \\
\hline & RW15 & 0.856 & 0.767 & & \\
\hline & RW16 & 0.705 & 0.706 & & \\
\hline \multirow[t]{4}{*}{ RW Ease of use } & RW01 & 0.884 & 0.833 & 3.569 & 15.517 \\
\hline & RW02 & 0.889 & 0.830 & & \\
\hline & RW04 & 0.843 & 0.770 & & \\
\hline & RW05 & 0.806 & 0.759 & & \\
\hline \multirow[t]{3}{*}{ RW Price offered } & RW06 & 0.588 & 0.656 & 1.588 & 6.905 \\
\hline & RW07 & 0.884 & 0.837 & & \\
\hline & RW08 & 0.472 & 0.656 & & \\
\hline \multirow[t]{3}{*}{ RW Peer experience } & RW09 & 0.774 & 0.733 & 2.436 & 10.593 \\
\hline & RW10 & 0.779 & 0.730 & & \\
\hline & RW11 & 0.793 & 0.707 & & \\
\hline \multirow[t]{3}{*}{ BW Information usefulness } & BW14 & 0.770 & 0.684 & 2.016 & 8.766 \\
\hline & BW15 & 0.834 & 0.745 & & \\
\hline & BW16 & 0.754 & 0.782 & & \\
\hline \multirow[t]{4}{*}{ BW Ease of use } & BW01 & 0.882 & 0.854 & 3.253 & 14.142 \\
\hline & BW02 & 0.833 & 0.776 & & \\
\hline & BW04 & 0.847 & 0.792 & & \\
\hline & BW05 & 0.674 & 0.793 & & \\
\hline \multirow[t]{3}{*}{ BW Price offered } & BW06 & 0.759 & 0.767 & 2.722 & 11.833 \\
\hline & BW07 & 0.834 & 0.819 & & \\
\hline & BW08 & 0.845 & 0.792 & & \\
\hline \multicolumn{6}{|c|}{ 1) $\mathrm{RW}=$ Customer review website; $\mathrm{BW}=$ Hotel brand website } \\
\hline
\end{tabular}


offered, and information usefulness. For the characteristics of consumer review website, there were four factors including, ease of use, price offered, information usefulness, and peer experience factors. The results confirmed that the constructs ease of use, price offered, and information factors were the same between the case of the consumer review website and that of the hotel brand website. Thus, we are able to compare the effects of these factors on consumer responses between the two websites.

\section{Testing Measurement Model}

The measurement of the reliability and validity of the seven factors for website characteristics, together with the measurement of the consumer response to Consumer review websites were confirmed using the partial least squares structural equation model (PLS-SEM).

Table 3. Scale composite reliability, validity, and internal consistency

\begin{tabular}{|c|c|c|c|c|c|c|c|}
\hline Variables & & Coefficients & $\mathrm{t}$ & $\begin{array}{c}\text { Cronbach's } \\
\text { Alpha }\end{array}$ & rho_A & $\begin{array}{c}\text { Composite } \\
\text { Reliability } \\
\text { (CR) }\end{array}$ & $\begin{array}{c}\text { Average } \\
\text { Variance } \\
\text { Extracted } \\
(\text { AVE) }\end{array}$ \\
\hline \multirow{3}{*}{$\begin{array}{l}\text { RW } \\
\text { Information } \\
\text { usefulness }\end{array}$} & RW14 & $0.688^{* * *}$ & 12.997 & 0.726 & 0.789 & 0.841 & 0.640 \\
\hline & RW15 & $0.823^{* * *}$ & 27.006 & & & & \\
\hline & RW16 & $0.878^{* * *}$ & 48.022 & & & & \\
\hline \multirow{4}{*}{$\begin{array}{l}\text { RW } \\
\text { Ease of use }\end{array}$} & RW01 & $0.912^{* * *}$ & 59.906 & 0.907 & 0.913 & 0.935 & 0.783 \\
\hline & RW02 & $0.905^{* * *}$ & 48.073 & & & & \\
\hline & RW04 & $0.878^{* * *}$ & 38.145 & & & & \\
\hline & RW05 & $0.842^{* * *}$ & 30.541 & & & & \\
\hline \multirow{3}{*}{$\begin{array}{l}\text { RW } \\
\text { Price offered }\end{array}$} & RW06 & $0.784^{* * *}$ & 22.662 & 0.694 & 0.721 & 0.827 & 0.616 \\
\hline & RW07 & $0.726^{* * *}$ & 14.008 & & & & \\
\hline & RW08 & $0.840^{* * *}$ & 34.691 & & & & \\
\hline \multirow{3}{*}{$\begin{array}{l}\text { RW } \\
\text { Peer experience }\end{array}$} & RW09 & $0.833^{* * *}$ & 23.662 & 0.789 & 0.796 & 0.876 & 0.702 \\
\hline & RW10 & $0.865^{* * *}$ & 34.566 & & & & \\
\hline & RW11 & $0.815^{* * *}$ & 21.579 & & & & \\
\hline \multirow{3}{*}{$\begin{array}{l}\text { BW } \\
\text { Information } \\
\text { usefulness }\end{array}$} & BW14 & $0.880^{* * *}$ & 13.796 & 0.751 & 0.895 & 0.843 & 0.642 \\
\hline & BW15 & $0.761^{* * *}$ & 5.662 & & & & \\
\hline & BW16 & $0.757^{* * *}$ & 5.758 & & & & \\
\hline \multirow{4}{*}{$\begin{array}{l}\text { BW } \\
\text { Ease of use }\end{array}$} & BW01 & $0.973^{* * *}$ & 3.646 & 0.904 & 0.943 & 0.903 & 0.706 \\
\hline & BW02 & $0.893^{* * *}$ & 3.871 & & & & \\
\hline & BW04 & $0.828^{* * *}$ & 3.548 & & & & \\
\hline & BW05 & $0.627^{* *}$ & 2.282 & & & & \\
\hline \multirow{3}{*}{$\begin{array}{l}\text { BW } \\
\text { Price offered }\end{array}$} & BW06 & $0.749^{* * *}$ & 3.444 & 0.861 & 1.162 & 0.902 & 0.756 \\
\hline & BW07 & $0.962^{* * *}$ & 4.999 & & & & \\
\hline & BW08 & $0.884^{* * *}$ & 4.889 & & & & \\
\hline \multirow{3}{*}{$\begin{array}{l}\text { Consumer } \\
\text { response }\end{array}$} & Satisfaction & $0.875^{* * *}$ & 41.117 & 0.850 & 0.851 & 0.909 & 0.770 \\
\hline & $\begin{array}{l}\text { Purchase } \\
\text { intention }\end{array}$ & $0.873^{* * *}$ & 44.067 & & & & \\
\hline & Decision change & $0.884^{* * *}$ & 49.898 & & & & \\
\hline
\end{tabular}

In Table 3, the results suggest that the factor loadings of all items exhibit values above 0.650 . The composite reliabilities of the measurement 
constructs ranged from $0.827-0.935$, indicating internal consistency of the measurement. Additionally, the average variance extracted (AVE) indices were between 0.612 and 0.783 , which were higher than 0.500 , representing convergent validity.

The Fornell and Larcker (1981) criterion was applied to examine the discriminant validity; the square root of each endogenous construct's AVE was compared to its bivariate correlations with all opposing endogenous constructs. Table 4 indicates that correlation coefficients between latent constructs were less than the square root of the AVE indices of the related latent constructs, representing the discriminant validity of the measurement.

Table 4. Discriminant validity

\begin{tabular}{llcccccccc}
\hline \multicolumn{1}{c}{ Variables } & F1 & F2 & F3 & F4 & F5 & F6 & F7 & F8 \\
\hline F1 & RW Information usefulness & $\underline{\mathbf{0 . 8 0 0}}$ & & & & & & & \\
F2 & RW Ease of use & 0.357 & $\underline{\mathbf{0 . 8 8 5}}$ & & & & & & \\
F3 & RW Price offered & 0.404 & 0.491 & $\underline{\mathbf{0 . 7 8 5}}$ & & & & & \\
F4 & RW Peer experience & 0.427 & 0.388 & 0.565 & $\underline{\mathbf{0 . 8 3 8}}$ & & & & \\
F5 & BW Information usefulness & 0.161 & 0.205 & 0.170 & 0.108 & $\underline{\mathbf{0 . 8 0 1}}$ & & & \\
F6 & BW Ease of use & 0.189 & 0.219 & 0.143 & 0.190 & 0.253 & $\underline{\mathbf{0 . 8 4 0}}$ & & \\
F7 & BW Price offered & 0.237 & 0.133 & 0.230 & 0.251 & 0.292 & 0.435 & $\underline{\mathbf{0 . 8 7 0}}$ & \\
F8 & Consumer response & 0.566 & 0.515 & 0.514 & 0.432 & 0.242 & 0.097 & 0.115 & $\underline{\mathbf{0 . 8 7 7}}$ \\
\hline \multicolumn{2}{l}{ Note: } & 1) diagonal = Square root of AVEs. & & & & & & &
\end{tabular}

\section{Structural Model and Hypothesis Testing}

The influence of website characteristics on consumer response with the degree of risk aversion and consumer involvement as moderators was examined using PLS-SEM. The method was used because it was most suitable for investigating the effects of independent variables with limited sample size.

There were three submodels in the analysis (Table 5). The first model investigated the impact of Consumer review website characteristics on consumer response. Then, the factors for hotel brand website were introduced in model 2. Finally, the moderating effects of consumer involvement and risk aversion were incorporated in model 3. Table 6 presents the reliability of the risk aversion and consumer involvement measurement. The $\mathrm{R}^{2}$ value increased from 0.472 in model 1 to 0.494 in model 2 and finally to 0.578 in model 3 . The value of $R^{2}$ represents the moderate prediction power of the analysis model (Hair et al., 2014). This may due to the reason which there would be some other factors influencing 
hotel online booking behavior that were not included in this study, such as customer-manager engagement (Han \& Anderson, 2020) or loyalty program from the hotel ( $\mathrm{O}^{\prime}$ Connor, 2021). However, the increasing of $\mathrm{R}^{2}$ suggests that incorporating hotel brand website as well as the effects of risk aversion and consumer involvement in the analysis can contribute to improving the prediction power of the model.

Table 5. Analysis Results

\begin{tabular}{|c|c|c|c|c|c|c|}
\hline & \multicolumn{2}{|c|}{ Model 1} & \multicolumn{2}{|c|}{ Model 2} & \multicolumn{2}{|c|}{ Model 3} \\
\hline & $\begin{array}{c}\text { Coefficient } \\
(\beta)\end{array}$ & $\mathrm{t}$ & $\begin{array}{c}\text { Coefficient } \\
(\beta)\end{array}$ & $\mathrm{t}$ & $\begin{array}{c}\text { Coefficient } \\
(\beta)\end{array}$ & $\mathrm{t}$ \\
\hline$R^{2}$ & 0.472 & & 0.494 & & 0.578 & \\
\hline RW Information usefulness & $0.365^{* * *}$ & 6.029 & $0.371^{* * *}$ & 6.168 & $0.380^{* * *}$ & 6.375 \\
\hline RW Ease of use & $0.260^{* * *}$ & 5.223 & $0.252^{* * *}$ & 4.349 & $0.238^{* * *}$ & 4.056 \\
\hline RW Price offered & $0.204^{* * *}$ & 2.913 & $0.201^{* *}$ & 2.771 & $0.165^{* *}$ & 2.362 \\
\hline RW Peer experience & 0.060 & 1.153 & 0.082 & 1.487 & 0.045 & 0.810 \\
\hline BW Information usefulness & & & $0.130^{* *}$ & 2.048 & $0.114^{* *}$ & 2.125 \\
\hline BW Ease of use & & & -0.070 & 0.835 & $-0.132^{*}$ & 1.941 \\
\hline BW Price offered & & & -0.082 & 0.970 & -0.059 & 0.835 \\
\hline Risk aversion & & & & & $0.126^{* *}$ & 2.255 \\
\hline Risk aversion ${ }^{*} R W$ Information usefulness & & & & & 0.071 & 1.110 \\
\hline Risk aversion ${ }^{*} R W$ Ease of use & & & & & -0.126 & 1.608 \\
\hline Risk aversion ${ }^{*} R W$ Price offered & & & & & -0.026 & 0.259 \\
\hline Risk aversion * RW Peer experience & & & & & 0.093 & 1.157 \\
\hline Risk aversion * BW Information usefulness & & & & & -0.060 & 1.053 \\
\hline Risk aversion ${ }^{*} B W$ Ease of use & & & & & -0.065 & 0.783 \\
\hline Risk aversion * BW Price offered & & & & & 0.095 & 1.533 \\
\hline Consumer involvement & & & & & -0.060 & 1.111 \\
\hline Involvement ${ }^{*} R W$ Information usefulness & & & & & $-0.104^{* *}$ & 2.010 \\
\hline Involvement ${ }^{*} R W$ Ease of use & & & & & 0.123 & 1.441 \\
\hline Involvement ${ }^{*} R W$ Price offered & & & & & 0.111 & 1.202 \\
\hline Involvement ${ }^{*} R W$ Peer experience & & & & & -0.087 & 1.165 \\
\hline Involvement * BW Information usefulness & & & & & 0.023 & 0.315 \\
\hline Involvement ${ }^{*} B W$ Ease of use & & & & & 0.023 & 0.276 \\
\hline Involvement * BW Price offered & & & & & 0.039 & 0.473 \\
\hline
\end{tabular}

Note: $\quad$ 1) $R W=$ Consumer review website; $B W=$ Hotel brand website

2) ${ }^{* * *}=p<0.01 ;{ }^{* *}=p<0.05 ;{ }^{*}=p<0.1$

The results of model 3 were visualized in Figure 3, the analysis results indicate that the ease of use, price offered and information usefulness factors of consumer review websites positively affected consumer response to review websites. The most influential factor from the consumer review website was information usefulness $(\beta=0.380, p<0.01)$, followed by ease of use $(\beta=0.238, \mathrm{p}<0.01)$ and price offered $(\beta=0.165, \mathrm{p}<$ 0.05). Thus, H1, H3, and H5 were supported. However, the results showed that there was no significant effect on consumer response from peer experience on consumer review websites. Therefore, H7 was not supported. 
Table 6. Construct reliability of risk aversion and consumer involvement variables

\begin{tabular}{|c|c|c|c|c|c|c|}
\hline Variables & $\begin{array}{c}\text { Coefficients } \\
(\beta)\end{array}$ & $\mathrm{t}$ & $\begin{array}{c}\text { Cronbach's } \\
\text { Alpha }\end{array}$ & rho_A & $\begin{array}{c}\text { Composite } \\
\text { Reliability } \\
\text { (CR) }\end{array}$ & $\begin{array}{c}\text { Average } \\
\text { Variance } \\
\text { Extracted } \\
\text { (AVE) }\end{array}$ \\
\hline \multicolumn{7}{|l|}{ Risk aversion } \\
\hline Risk01 (Reverse) & $0.244^{* * *}$ & 2.625 & 0.802 & 0.820 & 0.841 & 0.282 \\
\hline Risk02 & $0.553^{* * *}$ & 7.142 & & & & \\
\hline Risk03 & $0.627^{* * *}$ & 8.691 & & & & \\
\hline Risk04 & $0.630^{* * *}$ & 13.557 & & & & \\
\hline Risk05 & $0.488^{* * *}$ & 5.506 & & & & \\
\hline Risk06 & $0.528^{* * *}$ & 5.904 & & & & \\
\hline Risk07 & $0.517^{* * *}$ & 7.244 & & & & \\
\hline Risk08 & $0.544^{* * *}$ & 7.197 & & & & \\
\hline Risk09 & $0.488^{* * *}$ & 5.866 & & & & \\
\hline Risk10 & $0.566^{* * *}$ & 8.235 & & & & \\
\hline Risk11 & $0.633^{* * *}$ & 11.948 & & & & \\
\hline Risk12 & $0.594^{* * *}$ & 9.391 & & & & \\
\hline Risk13 & $0.352^{* * *}$ & 3.913 & & & & \\
\hline Risk14 & $0.527^{* * *}$ & 7.428 & & & & \\
\hline \multicolumn{7}{|l|}{ Consumer involvement } \\
\hline Involvement01 & $0.786^{* * *}$ & 12.585 & 0.856 & 0.840 & 0.883 & 0.488 \\
\hline Involvement02 & $0.704^{* * *}$ & 8.812 & & & & \\
\hline Involvement03 & $0.750^{* * *}$ & 10.432 & & & & \\
\hline Involvement 04 & $0.527^{* * *}$ & 4.634 & & & & \\
\hline Involvement05 & $0.700^{* * *}$ & 8.574 & & & & \\
\hline Involvement06 & $0.657^{* * *}$ & 7.380 & & & & \\
\hline Involvement07 & $0.687^{* * *}$ & 8.592 & & & & \\
\hline Involvement 08 & $0.749^{* * *}$ & 10.694 & & & & \\
\hline
\end{tabular}

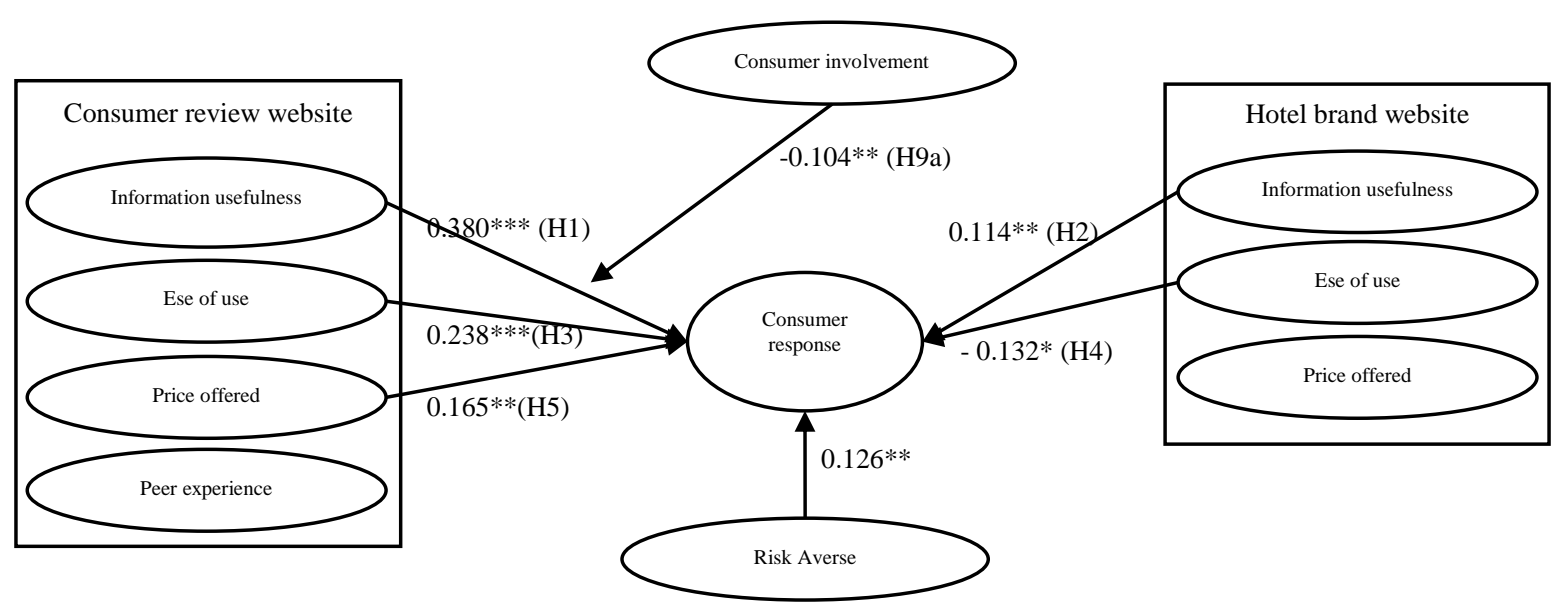

Figure 1. Results of model 3

(Note: 1) The insignificant paths were omitted. 2$)^{* * *}=p<0.01 ;^{* *}=p<0.05{ }^{*}=p<0.1$ )

Considering the effects of hotel brand website, it was found that the information usefulness of hotel brand website had a positive effect on consumer response to consumer review websites $(\beta=0.114, p<0.05)$. The results did not support $\mathrm{H} 2$, which hypothesized that the factor would negatively affect consumer response. The ease of use factor for hotel brand website negatively affected consumer response $(\beta=-0.132, \mathrm{p}<0.1)$, which 
supported H4. However, there was no significant effect of the price offered by hotel brand website; thus, H6 was not supported.

Regarding the effects of risk aversion, the results presented that there was a positive direct effect of risk aversion on consumer response $(\beta=0.126$, $p<0.05)$. However, there was no significant moderating effect of risk aversion on consumer response. Therefore, H8a-H8g were not supported.

Last, the consumer involvement factor has a negative moderating effect solely on the effect of consumer review website information usefulness $(\beta=-0.104, p<0.05)$, while there were no significant effects of consumer involvement on other characteristics of websites. Thus, H9a was supported, and $\mathrm{H} 9 \mathrm{~b}-\mathrm{H} 9 \mathrm{~g}$ were not supported.

\section{DISCUSSION AND IMPLICATIONS}

This study found that majority of the respondents $(90.07 \%)$ searched for hotel information on hotel brand website, and almost half of them began searching from hotel brand website before moving to consumer review websites $(48.34 \%)$. This implies that consumers try to search and compare hotel information from various sources, especially in the case that they are travelling to an unfamiliar place. Although, there were evidences that customer review website became a popular hotel booking channel among tourists (Liu \& Zhang, 2014; Martin-Fuentes \& Mellinas, 2018), this study confirmed that hotel managers still had to pay attention to hotel own websites. It is not only because the hotel website can create brand image and trust among consumer (Wang et al., 2015), but it also can help support information search and decision making on consumer review website.

The results from analysis models confirmed that the information usefulness, ease of use, and price offered factors were the key elements of the consumer review website motivating consumers to make hotel reservations. This result coincided with a previous study (Kim \& Kim, 2004). However, it was found that the review information was not the influential factor, as was found in past research (Zhao et al., 2015). This may be due to the level of analysis, that is, this research focused on the channel choice decision but not on the hotel choice. The peer experience information may not affect consumers' decision to make hotel reservations on consumer review websites, but it may affect how consumers evaluate the choice of hotel on websites that affect their trust in the hotel choice and thus their booking intentions (Kim et al., 2017). 
In addition to the characteristics of the consumer review website, the key contribution of this study is finding that hotel brand websites affect consumers' decisions on consumer review websites. This is a new discovery that was not studied before. Although, we hypothesized that the information usefulness of hotel brand website would discourage consumer to make reservation on customer review website, the results contrarily showed that the impact of the factor on consumer review website was positive. This means that consumers may refer to information on hotel brand website when they try to make hotel reservations on the review website. This assumption was supported by the respondents' characteristics shown in Table 1, in which more than $50 \%$ of respondents search for hotel information on both consumer review websites and hotel brand website before they decide. This suggests that hotel managers should continue to supply complete information on their official websites as well as on other intermediary websites such as review websites, although most of the transactions and reservations may not occur within their websites.

The study also found that the hotel brand website's ease of use factor had a negative effect on consumer response to the consumer review website. This implied that if the hotel can make their hotel brand website easy to use, it may lead consumers to make decisions on their website instead of on consumer review website. This may reduce the cost of profit sharing with the consumer review website.

Another key contribution of this study is that consumer risk aversion and consumer involvement were considered in the analysis. It was found that consumer risk aversion has a positive direct effect on consumer response to consumer review websites. This result is consistent with past studies that high-risk averse travelers tend to made decision based on review information (Casaló et al., 2015b). This lead them to make their hotel reservations on consumer review websites.

However, the result reports that consumer involvement negatively moderated the effect of the review website's information usefulness on consumer response. The interpretation of this result may be that consumers who are relatively highly involved with the hotel tend to pay less attention to the information on the review website and have a high tendency to not make hotel reservations on the consumer review website. This result supports the work of Bandi et al. (2018) that high involvement consumers tend to make decision based on information from other sources rather than consumer review website. Such findings can guide hotel managers to manage their customers based on risk aversion and consumer involvement. 
The consumer review website is the most likely channel for consumers who are highly risk averse and low involvement.

In conclusion, even though the study tried to compare the effects of the two types of websites, the results found that these two types of websites should cooperate to obtain consumers regardless of where the reservations are made. The hotel brand website still plays an important role in the hotel reservation process. It provides information about accommodations as well as the reservation channel for some consumers, i.e., high-involvement consumers. At the same time, the hotel must join the community or travel advisory sites that pull complete information from various sources. This type of travel community integrates various types of services such as destination, hotel, restaurant, events, and activity information. Moreover, it offers one-stop shopping where highly risk averse consumers can compare, share, and transact. Hotel groups and website developers can form a consortium or join forces with existing travel brokers or intermediaries to remain competitive in this fast-changing travel industry.

The limitation of this study is that the investigated hotel reservation behavior is under the condition that the respondents planning a vacation to an unfamiliar destination. Thus, factors impacting hotel reservation behavior under other travel objectives would be different. Further study with different travel objectives is recommended for future research. Also, this study focuses on how hotel brand website contributes to hotel bookings on consumer review website. Conversely, the study regarding the impact of information in consumer review website together with hotel brand website on hotel brand would be another research topic that can help managers utilize both websites in creating brand for hotel.

\section{REFERENCES}

Agag, G. M., \& El-Masry, A. A. (2017). Why do consumers trust online travel website? Drivers and outcomes of consumer trust toward online travel website. Journal of Travel Research, 56(3), 347-369.

Aziz, N. S., \& Kamaludin, A. (2014). Assessing website usability attributes using partial least squares. International Journal of Information and Electronics Engineering, 4(2), 137-144.

Bai, B., Law, R., \& Wen, I. (2008). The impact of website quality on customer satisfaction and purchase intentions: Evidence from Chinese online visitors. International Journal of Hospitality Management, 27(3), 391-402.

Beldad, A., De Jong, M., \& Steehouder, M. (2010). How shall I trust the faceless and the intangible? A literature review on the antecedents of online trust. Computers in Human Behavior, 26(5), 857-869.

Bandi Tanner, M., \& Hämmerli, S. J. (2018). Reviewing TripAdvisor and Co.: a quality analysis of hotel review sites. Anatolia, 29(4), 518-528. 
Bhatiasevi, V., \& Yoopetch, C. (2015). The determinants of intention to use electronic booking among young users in Thailand. Journal of Hospitality and Tourism Management, 23, 1-11.

Casaló, L.V., Flavián, C., \& Guinalíu, M. (2010). Determinants of the intention to participate in firm-hosted online travel communities and effects on consumer behavioral intentions. Tourism Management, 31(6), 898-911.

Casaló, L.V., Flavián, C., \& Guinalíu, M. (2011) Understanding the intention to follow the advice obtained in an online travel community. Computers in Human Behavior, 27(2), 622-633.

Casaló, L.V., Flavian, C., Guinaliu, M., \& Ekinci, Y. (2015a). Do online hotel rating schemes influence booking behaviors?. International Journal of Hospitality Management, 49, 28-36.

Casaló, L. V., Flavián, C., Guinalíu, M., \& Ekinci, Y. (2015b). Avoiding the dark side of positive online consumer reviews: Enhancing reviews' usefulness for high riskaverse travelers. Journal of Business Research, 68(9), 1829-1835.

Chiang, C.F., \& Jang, S.S. (2007). The effects of perceived price and brand image on value and purchase intention: Leisure travelers' attitudes toward online hotel booking. Journal of Hospitality E Leisure Marketing, 15(3), 49-69.

Davis, F.D. (1989). Perceived usefulness, perceived ease of use, and user acceptance of information technology. MIS quarterly, 13(3), 319-340.

Faryabi, M., Sadeghzadeh, K., \& Saed, M. (2012). The effect of price discounts and store image on consumer's purchase intention in online shopping context case study: Nokia and HTC. Journal of Business Studies Quarterly, 4(1), 197-205.

Filieri, R., Alguezaui, S., \& McLeay, F. (2015). Why do travelers trust TripAdvisor? Antecedents of trust towards consumer-generated media and its influence on recommendation adoption and word of mouth. Tourism Management, 51, 174-185.

Flanagin, A.J., \& Metzger, M.J. (2000). Perceptions of Internet information credibility. Journalism \& Mass Communication Quarterly, 77(3), 515-540.

Floyd, M. F., Gibson, H., Pennington-Gray, L., \& Thapa, B. (2004). The effect of risk perceptions on intentions to travel in the aftermath of September 11, 2001. Journal of Travel and Tourism Marketing, 15(2-3), 19-38.

Fornell, C. \& Larcker, D.F. (1981). Evaluating structural equation models with unobservable variables and measurement error. Journal of Marketing Research, 18(1), 39-50.

Goldsmith, R.E. \& Horowitz, D. (2006). Measuring motivations for online opinion seeking. Journal of Interactive Advertising, 6(2), 1-16.

Gursoy, D. (2019). A critical review of determinants of information search behavior and utilization of online reviews in decision making process (invited paper for 'luminaries' special issue of International Journal of Hospitality Management). International Journal of Hospitality Management, 76, 53-60.

Hair Jr, J. F., Sarstedt, M., Hopkins, L., \& Kuppelwieser, V. G. (2014). Partial least squares structural equation modeling (PLS-SEM): An emerging tool in business research. European Business Review, 26(2), 106-121.

Han, S., \& Anderson, C. K. (2020). The Effect of Private Customer-Manager Social Engagement Upon Online Booking Behavior. Cornell Hospitality Quarterly, 1938965520975330.

Jordan, E.J., Norman, W.C., \& Vogt, C.A. (2013). A cross-cultural comparison of online travel information search behaviors. Tourism Management Perspectives, 6, 15-22. 
Kapferer, J., \& Laurent, G. (1993). Further evidence on the consumer involvement profile: five antecedents of involvement. Psychology and Marketing, 10(4), 347-355.

Kim, H. W., \& Gupta, S. (2009). A comparison of purchase decision calculus between potential and repeat customers of an online store. Decision Support Systems, 47(4), 477-487.

Kim, W. G., \& Kim, D. J. (2004). Factors affecting online hotel reservation intention between online and non-online customers. International Journal of Hospitality Management, 23(4), 381-395.

Kim, S. Y., Kim, J. U., \& Park, S. C. (2017). The effects of perceived value, website trust and hotel trust on online hotel booking intention. Sustainability, 9(12), 2262; doi:10.3390/su9122262.

Kim, W. G., Ma, X., \& Kim, D. J. (2006). Determinants of Chinese hotel customers' esatisfaction and purchase intentions. Tourism Management, 27(5), 890-900.

Kim, E. E. K., Mattila, A. S., \& Baloglu, S. (2011). Effects of gender and involvement on consumers' motivation to read online hotel reviews. Cornell Hospitality Quarterly, 52(4), 399-406.

Laurent, G., \& Kapferer, J. (1985). Measuring consumer involvement profiles. Journal of Marketing Research, 22(1), 41-53.

Law, R., \& Hsu, C. H. (2006). Importance of hotel website dimensions and attributes: Perceptions of online browsers and online purchasers. Journal of Hospitality $\mathcal{E}$ Tourism Research, 30(3), 295-312.

Lehto, X. Y., Kim, D. Y., \& Morrison, A. M. (2006). The effect of prior destination experience on online information search behaviour. Tourism and Hospitality Research, 6(2), 160178.

Li, L., Peng, M., Jiang, N., \& Law, R. (2017). An empirical study on the influence of economy hotel website quality on online booking intentions. International Journal of Hospitality Management, 63, 1-10.

Li, X., \& Hitt, L. M. (2010). Price effects in online product reviews: An analytical model and empirical analysis. MIS quarterly, 34(4), 809-831.

Lien, C. H., Wen, M. J., Huang, L. C., \& Wu, K. L. (2015). Online hotel booking: The effects of brand image, price, trust and value on purchase intentions. Asia Pacific Management Review,20(4), 210-218.

Liu, J. N., \& Zhang, E. Y. (2014). An investigation of factors affecting customer selection of online hotel booking channels. International Journal of Hospitality Management, 39, 71-83.

Lockyer, T. (2005). The perceived importance of price as one hotel selection dimension. Tourism Management, 26(4), 529-537.

Martin-Fuentes, E., \& Mellinas, J. P. (2018). Hotels that most rely on Booking. com-online travel agencies (OTAs) and hotel distribution channels. Tourism Review, 73(4), 465479 .

Masiero, L., \& Law, R. (2016). Comparing reservation channels for hotel rooms: A behavioral perspective. Journal of Travel \& Tourism Marketing, 33(1), 1-13.

Mauri, A. G., \& Minazzi, R. (2013). Web reviews influence on expectations and purchasing intentions of hotel potential customers. International Journal of Hospitality Management, 34, 99-107.

McCarthy, L., Stock, D., \& Verma, R. (2010). How travelers use online social media channels to make hotel-choice decisions, how travelers use online and social media channels to make hotel-choice decisions. Cornell Hospitality Report, 10(18), 1-18. 
Morosan, C., \& Jeong, M. (2008). Users' perceptions of two types of hotel reservation websites. International Journal of Hospitality Management, 27(2), 284-292.

Money, R.B., \& Crotts, J.C. (2003). The effect of uncertainty avoidance on information search, planning, and purchases of international travel vacations. Tourism Management, 24(2), 191-202.

Nadiminti, R., Mukhopadhyay, T., \& Kriebel, C.H. (1996). Risk aversion and the value of information. Decision Support Systems, 16(3), 241-254.

O'Connor, P. (2021). Loyalty Programs and Direct Website Performance: An Empirical Analysis of Global Hotel Brands. In Information and Communication Technologies in Tourism 2021 (pp. 150-161). Cham: Springer.

Ong, B.S. (2012). The perceived influence of user reviews in the hospitality industry. Journal of Hospitality Marketing and Management, 21(5), 463-485.

Ongsakul, V., Ali, F., Wu, C., Duan, Y., Cobanoglu, C. and Ryu, K. (2021). Hotel website quality, performance, telepresence and behavioral intentions. Tourism Review, 76(3), 681-700.

Ozturk, A. B., Bilgihan, A., Nusair, K., \& Okumus, F. (2016). What keeps the mobile hotel booking users loyal? Investigating the roles of self-efficacy, compatibility, perceived ease of use, and perceived convenience. International Journal of Information Management, 36(6), 1350-1359.

Park, D. H., \& Lee, J. (2008). eWOM overload and its effect on consumer behavioral intention depending on consumer involvement. Electronic Commerce Research and Applications, 7(4), 386-398.

Park, D.H., Lee, J., \& Han, I. (2007). The effect of on-line consumer reviews on consumer purchasing intention: the moderating role of involvement. International Journal of Electronic Commerce, 11(4), 125-148.

Petty, R. E., Cacioppo, J. T., \& Schumann, D. (1983). Central and peripheral routes to advertising effectiveness: The moderating role of involvement. Journal of Consumer Research, 10(2), 135-146.

Quintal, V.A., Lee, J.A., \& Soutar, G.N. (2010). Tourists' information search: the differential impact of risk and uncertainty avoidance. International Journal of Tourism Research, 12(4), 321-333.

Ranganathan, C., \& Grandon, E. (2002). An exploratory examination of factors affecting online sales. Journal of Computer Information Systems, 42(3), 87-93.

Sigala, M. (2011a). eCRM 2.0 applications and trends: The use and perceptions of Greek tourism firms of social networks and intelligence. Computers in Human Behavior, 27(2), 655-661.

Sigala, M. (2011b). Preface: special issue on web 2.0 in travel and tourism: empowering and changing the role of travelers. Computers in Human Behavior, 27(2), 607-608.

Slevitch, L., \& Sharma, A. (2008). Management of perceived risk in the context of destination choice. International Journal of Hospitality and Tourism Administration, 9(1), 85-103.

Sparks, B.A., \& Browning, V. (2011). The impact of online reviews on hotel booking intentions and perception of trust. Tourism Management, 32(6), 1310-1323.

Sparks, B.A., So, K.K.F., \& Bradley, G.L. (2016). Responding to negative online reviews: The effects of hotel responses on customer inferences of trust and concern. Tourism Management, 53, 74-85.

Sun, S., Fong, L. H.N., Law, R., \& Luk, C. (2016). An Investigation of Gen-Y's Online Hotel Information Search: The Case of Hong Kong. Asia Pacific Journal of Tourism Research, 21(4), 443-456. 
Sun, S., Law, R., Luk, C., \& Fong, L. H. N. (2017). Channels for searching hotel and travel information. In Information and communication technologies in tourism 2017 (pp. 445458). Cham: Springer.

Tsao, W. C., Hsieh, M. T., Shih, L. W., \& Lin, T. M. (2015). Compliance with eWOM: The influence of hotel reviews on booking intention from the perspective of consumer conformity. International Journal of Hospitality Management, 46, 99-111.

Venkatesh, V., \& Davis, F. D. (2000). A theoretical extension of the technology acceptance model: Four longitudinal field studies. Management Science, 46(2), 186-204.

Wang, L., Law, R., Guillet, B. D., Hung, K., \& Fong, D. K. C. (2015). Impact of hotel website quality on online booking intentions: eTrust as a mediator. International Journal of Hospitality Management, 47, 108-115.

Wang, H. Y., \& Wang, S. H. (2010). Predicting mobile hotel reservation adoption: Insight from a perceived value standpoint. International Journal of Hospitality Management, 29(4), 598-608.

Wong, J., \& Law, R. (2005). Analysing the intention to purchase on hotel website: a study of travellers to Hong Kong. International Journal of Hospitality Management, 24(3), 311-329.

Xiang, Z., \& Gretzel, U. (2010). Role of social media in online travel information search. Tourism management, 31(2), 179-188.

Xie, K. L., Zhang, Z., \& Zhang, Z. (2014). The business value of online consumer reviews and management response to hotel performance. International Journal of Hospitality Management, 43, 1-12.

Yeung, T. A., \& Law, R. (2004). Extending the modified heuristic usability evaluation technique to chain and independent hotel website. International Journal of Hospitality Management, 23(3), 307-313.

Zhao, X., Wang, L., Guo, X., \& Law, R. (2015). The influence of online reviews to online hotel booking intentions. International Journal of Contemporary Hospitality Management, 27(6), 1343-1364. 


\section{Appendix A. Constructs and measurements}

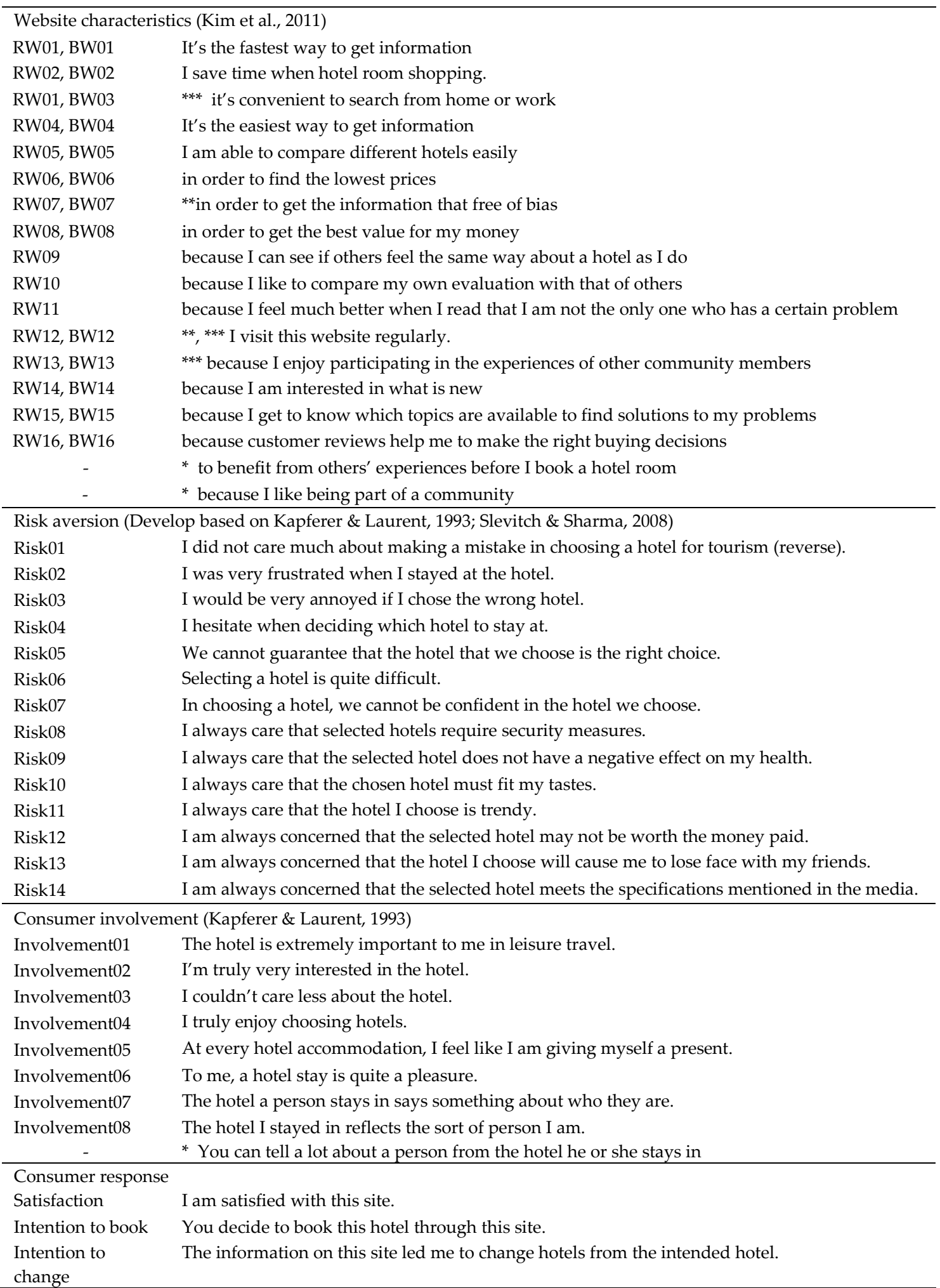

Note: ${ }^{*}=$ these questions were dropped according to the result from the pretest.

** $=$ this question was added according to the result from the pretest.

$* * *=$ these questions were dropped according to the result of principal component analysis.

$R W=$ Customer review website, $B W=$ Hotel brand website . 